\title{
Normal corneal endothelial cell density in Nigerians
}

\author{
This article was published in the following Dove Press journal: \\ Clinical Ophthalmology \\ 18 March 2016 \\ Number of times this article has been viewed
}

\author{
Temitope Ewete' \\ Efeoghene Uchenna Ani ${ }^{2}$ \\ Adegboyega Sunday Alabi' \\ 'MeCure Eye Center, Lagos, \\ ${ }^{2}$ Department of Ophthalmology, \\ University of Port Harcourt, Port \\ Harcourt, Nigeria
}

\begin{abstract}
Aim: The aim of the study was to describe the corneal endothelial cell density of adults at the MeCure Eye Center and to determine the relationship between age, sex, and corneal endothelial cell density.
\end{abstract}

Methods: This study was a retrospective study looking at those records of individuals who had undergone specular microscopy or corneal endothelial cell count measurement at the MeCure Eye Center.

Results: The endothelial cell characteristics of 359 healthy eyes of 201 volunteers were studied. The mean corneal endothelial cell density (MCD) was 2,610.26 \pm 371.87 cells $/ \mathrm{mm}^{2}$ (range, 1,484-3,571 cells $/ \mathrm{mm}^{2}$ ). The MCD decreased from 2,860.70 cells $/ \mathrm{mm}^{2}$ in the $20-30$-year age group to $2,493.06$ cells $/ \mathrm{mm}^{2}$ in the $>70$-year age group, and there was a statistically significant relationship between age and MCD with a $P$-value of $<0.001$. There was no statistically significant correlation between sex and corneal endothelial cell density $(P=0.45)$.

Conclusion: This study shows that endothelial cell density in Nigerian eyes is less than that reported in the Japanese, American, and Chinese eyes, and is comparable to that seen in Indian and Malaysian eyes.

Keywords: corneal, endothelial cell density, Nigerian

\section{Introduction}

The corneal endothelial cell density is essential in the clinical assessment of the cornea to determine its function and ability to respond to stress. It is important to determine a reference range for different population groups in order to establish abnormal values and aid predictability, especially with the noted increase in intraocular surgeries. The cornea is the transparent, clear tissue at the front and center of the eye, and it helps to maintain the transparency at the front of the eye, which enables a clear pathway for images to be viewed. The average corneal diameter is $11.5 \mathrm{~mm}$ vertically and $12 \mathrm{~mm}$ horizontally. ${ }^{1}$

The cornea consists of the following layers: the epithelium, the Bowman layer, the stroma, the Descemet's membrane, and the endothelium. The cornea endothelium is a very important factor in the optical transparency of the cornea, and this transparency is maintained by its ability to pump water out of the corneal stroma against an osmotic gradient; it also maintains corneal hydration. ${ }^{2,3}$ The cornea endothelium is metabolically active and utilizes the $\mathrm{Na}^{+}-\mathrm{K}^{+}$pump for keeping the stroma at its usual hydrated state of $70 \%$ water to prevent stromal edema. ${ }^{4}$ The average normal mean corneal endothelial cell density (MCD) is usually the highest at birth $\left(\sim 3,000\right.$ cells $\left./ \mathrm{mm}^{2}\right)$, and it declines slowly; a minimal density of $400-500$ cells $/ \mathrm{mm}^{2}$ is required to sustain the pumping activity of the endothelium, and values below this have been associated with bullous keratopathy. ${ }^{5}$

\section{Correspondence: Temitope Ewete MeCure Eye Center, MeCure House, Debo Industrial Compound, Oshodi- Apapa Expressway, Lagos, Nigeria Tel +2348053536090 Email temidemi2000@gmail.com} (c) ${ }_{\mathrm{BY}} \mathrm{NC}$ and incorporate the Creative Commons Attribution - Non Commercial (unported, v3.0) License (http://creativecommons.org/licenses/by-nc/3.0/). By accessing the work you hereby accept the Terms. Non-commercial uses of the work are permitted without any further permission from Dove Medical Press Limited, provided the work is properly attributed. For permission for commercial use of this work, please see paragraphs 4.2 and 5 of our Terms (https://www.dovepress.com/terms.php). 
Nowadays, various specular microscopic techniques and machines have made the evaluation of the endothelial density possible.

Damage to the human corneal endothelium consists of a healing process that includes a combination of cell enlargement and cell spread, and these processes create a layer of cells on the inner surface of the cornea ${ }^{6}$ The corneal endothelial wound repair is also reflected as an increase in the variation of individual cell areas, which is also described as the coefficient of variation (CV). Six-sided or hexagonal cells usually give an indication that there is an evenly distributed membrane surface tension, which can be equalized to normal cells and in the normal cornea; the percentage of the hexagonal cells is expected to be $60 \%$, which is decreased by stress. ${ }^{7}$ The less healthy the endothelium, the lower the endothelial cell count and the greater variation in cell size and shape. ${ }^{8}$

Corneal endothelial imaging can be contact or noncontact imaging. Noncontact endothelial imaging has the advantage of reducing the risk of corneal epithelial damage and artifacts during imaging. 7,9

Several studies have been carried out looking at corneal endothelial morphology in Turkish, Iranian, Filipino, American, Japanese, and different populations. ${ }^{9-12}$ This study gives additional data attributable to the Nigerian population that have not been published in the literature as far as the authors are aware of.

The specific objectives of this study were to describe the corneal endothelial cell density of adults at the MeCure Eye Center (Lagos, Nigeria) and to determine the relationship between age, sex, and corneal endothelial cell density.

\section{Materials and methods}

Ethical approval was obtained from the Ethical Committee of the Teaching Hospital of the University of Port Harcourt. Patient consent was not required as this was a retrospective study and all patient data was de-identified; however, approval was obtained from the MeCure Healthcare Limited Chief Operations Officer to retrieve the necessary patient data.

\section{Study design}

This study was a retrospective study looking at the records of individuals who had undergone specular microscopy or corneal endothelial cell count measurement at the MeCure Eye Center. The machine used was a Konan Medical NonCon Robo Specular Microscope X, Model No NSP-9900 (Konan Medical Inc., Nishinomiya, Japan), which was a noncontact specular microscope.

\section{Inclusion criteria}

The inclusion criteria were as follows: adults 20 years of age and above who were walk-in patients or volunteers from staff or relatives of patients; and adults who were born in Nigeria and/or had spent a minimum of 15 years in Nigeria. ${ }^{13}$

\section{Exclusion criteria}

The exclusion criteria were as follows: individuals younger than 20 years; non-Nigerian individuals; individuals with a previous history of ocular trauma; individuals with a past history of ocular surface disease; and individuals with a past history of ocular surgery or a past history of endothelial dysfunction.

\section{Data collection}

Information such as age, sex, eye measured, average cell density, standard deviation, average cell area, percentage of hexagonal cells, CV, maximum cell area, and minimum cell area as measured by the machine was retrieved and analyzed.

\section{Data analysis}

Data analysis was performed using SPSS software (Version 10.0; SPSS Inc., Chicago, IL, USA). The paired and unpaired $t$-tests and Pearson correlation analysis were also used. Analysis of variance and linear regression analysis were used to examine the change in endothelial cell characteristics with age. $P$-values $<0.05$ were determined as statistically significant.

\section{Results}

The endothelial cell characteristics of 359 healthy eyes of 201 volunteers were studied. There were 207 males and 152 females. The mean age of the population was $50.35 \pm 20.13$ years (range, 20-93 years). The MCD was 2,610.26 $\pm 371.87 \mathrm{cells} / \mathrm{mm}^{2}$ (range, 1,484-3,571 cells $/ \mathrm{mm}^{2}$ ). The mean cell area was $392.22 \pm 68.03 \mu \mathrm{m}^{2}$ (range, 280 $674 \mu \mathrm{m}^{2}$ ). The CV in the cell size was $43.95 \% \pm 9.50 \%$ (range, 25\%-96\%), and the percentage of hexagonal cells was $46.52 \% \pm 8.83 \%$ (range, $18 \%-78 \%$ ).

The MCD decreased from 2,860.70 cells $/ \mathrm{mm}^{2}$ in the 20-30year age group to $2,493.06$ cells $/ \mathrm{mm}^{2}$ in the $>70$-year age group (Table 1), and there was a statistically significant relationship between age and MCD with a $P$-value of $<0.001$.

The average corneal endothelial cell density was seen to be higher in females than in males, but it should also be noted that there were more males in this study than females. There was no statistically significant correlation between sex and corneal endothelial cell density $(P=0.45$; Table 2$)$.

There were significant correlations between age and MCD $(r=-0.318, P<0.001$; Figure 1). 
Table I Characteristics of the endothelial cells in different age groups of the study population

\begin{tabular}{|c|c|c|c|c|c|}
\hline $\begin{array}{l}\text { Age } \\
\text { (years) }\end{array}$ & Patients (n) & $\begin{array}{l}\text { Mean corneal endothelial cell } \\
\text { density (cells } / \mathbf{m m}^{2} ; \text { mean } \pm \text { SD) }\end{array}$ & $\begin{array}{l}\text { Hexagonality } \\
(\% ; \text { mean } \pm \text { SD) }\end{array}$ & $\begin{array}{l}\text { CV in cell size } \\
(\% ; \text { mean } \pm S D)\end{array}$ & $\begin{array}{l}\text { Mean cell area } \\
\left(\mu \mathrm{m}^{2} ; \text { mean } \pm \mathrm{SD}\right)\end{array}$ \\
\hline $20-30$ & 81 & $2,860.70 \pm 227.06$ & $50.83 \pm 7.26$ & $4 \mathrm{I} .44 \pm 7.3 \mathrm{I}$ & $351.25 \pm 31.00$ \\
\hline $31-40$ & 62 & $2,631.26 \pm 394.70$ & $43.40 \pm 8.68$ & $45.47 \pm 9.86$ & $391.42 \pm 77.95$ \\
\hline $4 I-50$ & 31 & $2,433.74 \pm 442.42$ & $43.00 \pm 10.32$ & $48.16 \pm 11.73$ & $426.23 \pm 88.7 \mid$ \\
\hline $5 I-60$ & 37 & $2,545.03 \pm 319.73$ & $45.38 \pm 9.21$ & $42.38 \pm 7.73$ & $400.00 \pm 60.02$ \\
\hline $6 I-70$ & 81 & $2,538.04 \pm 362.48$ & $46.40 \pm 8.15$ & $43.70 \pm 10.88$ & $403.04 \pm 66.19$ \\
\hline$>70$ & 67 & $2,493.06 \pm 353.35$ & $46.63 \pm 8.68$ & $44.79 \pm 8.72$ & $409.79 \pm 66.7$ I \\
\hline Total & 359 & $2,6|0.26 \pm 37| .87$ & $46.52 \pm 8.83$ & $43.95 \pm 9.50$ & $392.22 \pm 68.03$ \\
\hline
\end{tabular}

Abbreviation: $\mathrm{CV}$, coefficient of variation.

Table 2 Average corneal endothelial cell density in males and females

\begin{tabular}{lll}
\hline Age group (years) & $\begin{array}{l}\text { Male cell density } \\
\left.\text { (cells } / \mathbf{m m}^{2} ; \text { mean } \pm \mathbf{S D}\right)\end{array}$ & $\begin{array}{l}\text { Female cell density } \\
\text { (cells/mm } \mathbf{m m}^{2} \text { mean } \pm \mathbf{S D} \text { ) }\end{array}$ \\
\hline $20-30$ & $2,859.12 \pm 225.77$ & $2,861.79 \pm 230.33$ \\
$31-40$ & $2,637.09 \pm 350.42$ & $2,624.18 \pm 449.21$ \\
$4 I-50$ & $2,409.57 \pm 421.38$ & $2,503.25 \pm 522.85$ \\
$5 \mathrm{I}-60$ & $2,629.00 \pm 275.31$ & $2,318.30 \pm 334.17$ \\
$61-70$ & $2,562.14 \pm 389.12$ & $2,497.07 \pm 314.08$ \\
$>70$ & $2,477.00 \pm 403.985$ & $2,515.43 \pm 273.17$ \\
Total & $2,597.52 \pm 375.94$ & $2,627.61 \pm 366.77$ \\
\hline
\end{tabular}

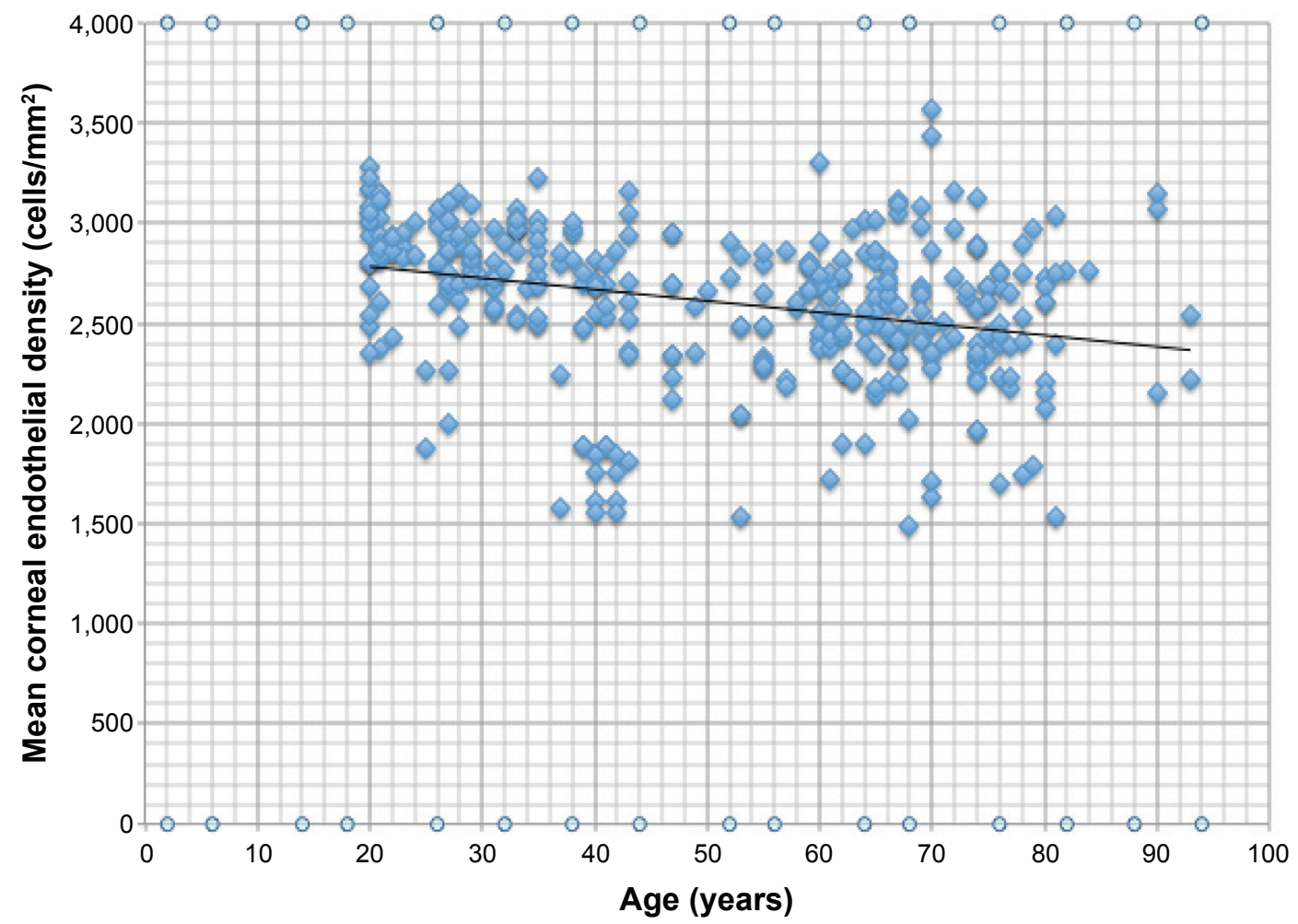

Figure I Scatter plots show correlation between age and the mean corneal endothelial cell density. 


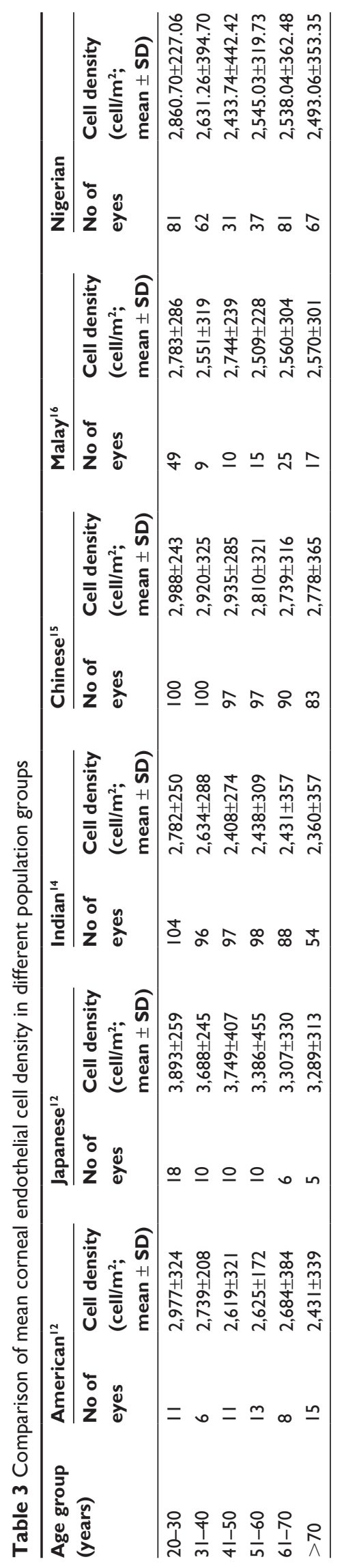

\section{Discussion}

Corneal endothelial cell analysis is important toward predicting the viability of the cornea especially after intraocular procedures like cataract surgery. Different studies have shown significant differences in corneal endothelial properties among races and ethnic groups. ${ }^{10-12,14,16,17}$ The MCD obtained in this study $\left(2,610.26 \pm 371.87 \mathrm{cells} / \mathrm{mm}^{2}\right)$ revealed results similar to values obtained in Indian eyes (Table 3). ${ }^{14}$ These values are low compared to the results obtained from the Japanese eyes (Table 3 ). ${ }^{12}$

There is also a similar trend of decrease in MCD with advancing age as seen in various other studies. ${ }^{12,14,15}$ There was no significant relationship between MCD and sex even though females in the study had higher values than the males (Table 2). It is not immediately clear the reason for the disparity; similarly, in Filipinos, females are reported to have higher MCD than males and a slight increase with age up to 40 years before a slight decline with age in both sexes. ${ }^{11}$

Regression analysis done showed significant correlations between age and $\operatorname{MCD}(r=-0.318, P<0.001$; Figure 1$)$. The results of this study have also shown that with increasing age, there is also a general trend toward a decline in MCD, hexagonality, variation in cell size (CV), and mean cell area (Table 1). These findings are in agreement with many previous studies. ${ }^{10,11,14,18}$ This study confirms the previous report that MCD correlates with age and that endothelial cell count decreases with increasing age. ${ }^{17}$

It had been hypothesized that the differences in MCD between different populations might be as a direct result of variations in corneal diameter and endothelial surface area, but it is difficult for this relationship to be ascertained in this study as corneal diameter was not measured. ${ }^{14}$

\section{Conclusion}

In conclusion, this study reports normative endothelial characteristics in a Nigerian population that may serve as a useful baseline for future studies. This study has reported a decrease in MCD with age. There was no statistically significant difference in MCD between sexes. Comparison with previous studies indicates that endothelial cell density in the Nigerian eyes is less than that reported in the Japanese, American, and Chinese eyes, and is comparable to Indian and Malaysian eyes.

\section{Disclosure}

The authors report no conflicts of interest in this work. 


\section{References}

1. Kanski JJ, Bowling B, editors. Chapter 6. In: Clinical Ophthalmology. A Systematic Approach. Seventh ed. Philadelphia, PA: Elsevier; 2011:168.

2. Arici C, Arslan OS, Dikkaya F. Corneal endothelial cell density and morphology in healthy Turkish eyes. J Ophthalmol. 2014;2014:852624.

3. Wilson RS, Roper-Hall MJ. Effect of age on the endothelial cell count in the normal eye. Br J Ophthalmol. 1982;66(8):513-515.

4. Kirk RW. Basic and Clinical Science Course Section 8 2004-2005; External Disease and Cornea. San Francisco, CA: American Academy of Ophthalmology; 2005:32-33.

5. Ventura AC, Wälti R, Böhnke M. Corneal thickness and endothelial density before and after cataract surgery. Br J Ophthalmol. 2001;85(1): 18-20.

6. McCarey BE, Edelhauser HF, Lynn MJ. Review of corneal endothelial specular microscopy for FDA clinical trials of refractive procedures, surgical devices and new intraocular drugs and procedures. Cornea. 2008;27(1):1-16.

7. Bourne WM, McLaren JW. Clinical responses of the corneal endothelium. Exp Eye Res. 2004;78:561-572.

8. Rapuano CJ, Luchs JI, Kim T. Anterior Segment. The Requisites in Ophthalmolgy. 1st ed. Mosby Publishers, Maryland Heights, MO; 2000:228.

9. Hashemian MN, Moghimi S, Fard MA, Fallah MR, Mansouri MR. Corneal endothelial cell density and morphology in normal Iranian eyes. BMC Ophthalmol. 2006;6:9.
10. Padilla MD, Sibayan SA, Gonzales CS. Corneal endothelial cell density and morphology in normal Filipino eyes. Cornea. 2004;23:129-135.

11. Snellingen T, Rao GN, Shrestha JK, Huq F, Cheng H. Quantitative and morphological characteristics of the human corneal endothelium in relation to age, gender, and ethnicity in cataract populations of South Asia. Cornea. 2001;20:55-58.

12. Matsuda M, Yee RW, Edelhauser HF. Comparison of the corneal endothelium in an American and a Japanese population. Arch Ophthalmol. 1985; 103:68-70.

13. Nigerian Nationality Law. Wikipedia. Available from: https://en.wikipedia.org/wiki/Nigerian_nationality_law. Accessed September 24, 2015.

14. Rao SK, Ranjan Sen P, Fogla R, et al. Corneal endothelial cell density and morphology in normal Indian eyes. Cornea. 2000;19:820-823.

15. Yunliang S, Yuqiang H, Ying-peng L, Ming-zhi Z, Lam DSC, Rao SK Corneal endothelial cell density and morphology in healthy Chinese eyes. Cornea. 2007;26:130-132.

16. Mohammed-Salih PA. Corneal endothelial cell density and morphology in normal Malay eyes. Med J Malaysia. 2011;66(4):300-303.

17. Laule A, Cable MK, Hoffman CE, Hanna C. Endothelial cell population changes of human cornea during life. Arch Ophthalmol. 1978;96: 2031-2035.

18. Galgauskas S, Krasauskaite D, Pajaujis M, Juodkaite G, Asoklis R-S. Central corneal thickness and corneal endothelial characteristics in healthy, cataract, and glaucoma patients. Clin Ophthalmol. 2012;6: 1195-1199.
Clinical Ophthalmology

\section{Publish your work in this journal}

Clinical Ophthalmology is an international, peer-reviewed journal covering all subspecialties within ophthalmology. Key topics include: Optometry; Visual science; Pharmacology and drug therapy in eye diseases; Basic Sciences; Primary and Secondary eye care; Patient Safety and Quality of Care Improvements. This journal is indexed on

Submit your manuscript here: http://www.dovepress.com/clinical-ophthalmology-journal

\section{Dovepress}

PubMed Central and CAS, and is the official journal of The Society of Clinical Ophthalmology (SCO). The manuscript management system is completely online and includes a very quick and fair peer-review system, which is all easy to use. Visit http://www.dovepress.com/ testimonials.php to read real quotes from published authors. 